\title{
High Mortality and Low Net Change in Live Woody Biomass of Karst Evergreen and Deciduous Broad-Leaved Mixed Forest in Southwestern China
}

\author{
Libin Liu ${ }^{1,2}$, Jian $\mathrm{Ni}^{1,2,3, *}$, Qiaolian Zhong ${ }^{2,3}$, Gang $\mathrm{Hu}^{4,5}$ and Zhonghua Zhang ${ }^{4,5}$ \\ 1 College of Chemistry and Life Sciences, Zhejiang Normal University, Yingbin Avenue 688, Jinhua 321004, \\ China; liulibin@zjnu.cn \\ 2 Puding Karst Ecosystem Research Station, Chinese Academy of Sciences, Shawan at Longga Village, Puding, \\ Anshun 562100, China; zhongqiaolian@mail.gyig.ac.cn \\ 3 State Key Laboratory of Environmental Geochemistry, Institute of Geochemistry, \\ Chinese Academy of Sciences, Lincheng West Road 99, Guiyang 550081, China \\ 4 School of Environment and Life Science, Guangxi Teachers Education University, Mingxiu East Road 175, \\ Nanning 530001, China; ahhugang@gmail.com (G.H.); gxtczzh@gmail.com (Z.Z.) \\ 5 Key Laboratory of Beibu Gulf Environment Change and Resources Utilization of the Ministry of Education, \\ Guangxi Teachers Education University, Mingxiu East Road 175, Nanning 530001, China \\ * Correspondence: nijian@zjnu.edu.cn; Tel.: +86-579-8228-7521
}

Received: 27 March 2018; Accepted: 9 May 2018; Published: 11 May 2018

\begin{abstract}
Repeated observation based on large permanent monitoring plots is a key method for directly understanding forest regeneration dynamics. Karst forests grow slowly in adverse habitats and possess a special regeneration mode. However, no data can support these properties because no repeated observations have been performed. The mortality, recruitment, and net change in live woody biomass $\left(\mathrm{NPP}_{\mathrm{lw}}\right)$ of a karst evergreen and deciduous broad-leaved mixed forest in Central Guizhou Province, Southwestern China, were studied on the basis of a short-term continuous monitoring ( 3 years) of a 2 ha plot. The species richness of individuals with a diameter at breast height $(\mathrm{DBH}) \geq 1 \mathrm{~cm}$ decreased from 66 to 58 during the study period. Eight species disappeared, and no new species appeared. The individual number declined from 16,821 to 15,003 because most species indicated more deaths than recruitments. Trees presented the lowest mortality rate, and shrubs presented the highest recruitment rate among the species. Individual death number decreased with the increase in DBH classes. The estimated aboveground $\mathrm{NPP}_{\mathrm{lw}}$ was $8.41 \mathrm{t} \mathrm{ha}^{-1}$ year $^{-1}$. The survivors, recruitments, and deaths contributed $10.88,0.11$, and $-2.58 \mathrm{t} \mathrm{ha}^{-1}$ year $^{-1}$, respectively. Trees $\left(8.37 \mathrm{t} \mathrm{ha}^{-1}\right.$ year $\left.{ }^{-1}\right)$, rather than shrubs $\left(0.04 \mathrm{tha}^{-1}\right.$ year $\left.^{-1}\right)$ and lianas $\left(-0.004 \mathrm{tha}^{-1}\right.$ year $\left.^{-1}\right)$, were the major contributors. The karst forest presented higher mortality and lower $\mathrm{NPP}_{l w}$ than nonkarst forests in subtropical China and in the world.
\end{abstract}

Keywords: regeneration dynamics; net change in live woody biomass; short-term continuous monitoring; karst forest; carbon cycling

\section{Introduction}

Community dynamics such as mortality, recruitment, and net primary productivity (NPP) have been extensively studied in forest ecology [1]. Due to the long dynamic period of forests, multifarious indirect research methods, such as succession sequence, dendrochronology, pollen analysis, and vegetation modelling, have been used to explore forest dynamics indirectly [2-4]. However, these methods demonstrate disadvantages [5-9]. In recent years, long-term repeated observations based on large permanent monitoring plots have become a key method for directly 
understanding forest regeneration dynamics and mechanisms of species coexistence, biodiversity, and carbon cycling [8-11]. Numerous large plots that consist of various types of vegetation have been established worldwide, and have been continuously monitored in the long term [12].

China, a country with abundant forest resources, covers the majority of forest types worldwide from boreal forests to tropical rain forests. Thus, conducting long-term and continuous observations of China's forests to determine their regeneration and growth dynamics will contribute considerably to global biodiversity maintenance and carbon cycling [13-17]. Owing to establishing the protocol of global forest dynamics permanent plots [10], many large plots that consist of tropical mountain rain forest [18], subtropical evergreen broad-leaved forest [19-23], subtropical evergreen and deciduous broad-leaved mixed forest [24], temperate coniferous and broad-leaved mixed forests [25,26], temperate coniferous forest [27], and temperate deciduous broad-leaved forests $[9,27]$ in China were established. Forest regeneration dynamics were also investigated and reported.

Southwestern China, the Mediterranean coast of Europe, and the Eastern United States are the three major regions worldwide with extensively distributed continuous karst landscapes. Vegetation in karst landscape (commonly called karst vegetation) is fragile to human disturbances given the special features of high rates of limestone outcrops, shallow soils, water leakage, and remarkable heterogeneity of habitats. Reverse succession frequently occurs when vegetation is destroyed. Thus, degraded vegetation (e.g., shrublands, tussocks, and grasslands) are widely distributed; rocky desertification-a desert-like landscape with exposed rock—can also be commonly observed [28,29]. Primary and even secondary forests are only distributed in certain nature reserves and remote hilltops with minimal human disturbances. Therefore, existing forests in karst regions play important roles in the prevention of rocky desertification, water conservation, biodiversity conservation, vegetation restoration and recovery, and carbon sequestration [29]. In the past few years, community composition and structure, biodiversity, community succession, biomass and vegetation restoration of karst forests in Southwestern China and other parts of the world have been studied [30-42]. However, all existing studies are based on single investigations. No repeated investigations have been conducted, and the dynamic process of community composition and functions of karst forests have not been explored.

Zhu et al. [43] reported that the diameter at breast height (DBH), height, and mass growth of trees in a karst forest in Southern Guizhou increase slowly on the basis of stem analysis. Thus, karst forest must be a low-NPP forest. Ni et al. [44] estimated the aboveground NPP change in live woody biomass $\left(\mathrm{ANPP}_{\mathrm{lw}}\right)$ of two dominant tree species in a karst forest in Central Guizhou using tree-ring width, girth increment, and biomass models; these authors also further estimated the forest $\mathrm{ANPP}_{1 \mathrm{w}}$ on the basis of the average $\mathrm{ANPP}_{l_{\mathrm{w}}}$ of two tree species and stand density, and verified that the $\mathrm{ANPP}_{\mathrm{lw}_{\mathrm{w}}}$ was lower in the karst forest than in the natural subtropical nonkarst forests in China and in the world [45-47]. However, this NPP estimation method is accompanied by significant uncertainties caused by a selection of species and individuals. Thus, the NPP estimation of karst forests based on continuous monitoring must be conducted.

Saplings and small trees under adverse habitats are more likely to die in karst forests than in nonkarst forests; in addition, saplings frequently replace small and medium trees that die on the vine, rather than replace naturally aging old trees. This phenomenon is a special regeneration mode of karst forests, but without supporting data [48]. In the present study, a typical karst evergreen and deciduous broad-leaved mixed forest in a 2-ha permanent monitoring plot in Central Guizhou Plateau, Southwestern China, was investigated as an example. On the basis of the survey data obtained in 2012 and 2015, the regeneration dynamics and $\mathrm{NPP}_{l_{\mathrm{w}}}$ of the karst forest were analysed for the first time. The regeneration dynamics include species and individual mortality, recruitment and their distribution among life forms (e.g., trees, shrubs, and lianas), and DBH classes. The present study is aimed at revealing the general short-term regeneration process of a karst forest and further evaluating whether the $\mathrm{NPP}_{1 \mathrm{w}}$ is lower in karst forests than in nonkarst forests in subtropical China and in the world. Such studies will provide basic data for improving forest management and restoration in karst regions. 


\section{Materials and Methods}

Field measurements were conducted in the Tianlongshan permanent monitoring plot $\left(105^{\circ} 45^{\prime} 50^{\prime \prime} \mathrm{E}\right.$, $26^{\circ} 14^{\prime} 40^{\prime \prime}$ N, 1402-1512 m) of the Puding Karst Ecosystem Research Station in Puding County, Central Guizhou Province, Southwestern China (Figure 1). The karst terrain in the study area exhibits a plateau-surface karst morphology, which is a karst morphological type in Southwestern China [49]. This area lies in mid-subtropical China, and is classified as a monsoon climate. According to the records from the Puding weather station $\left(105^{\circ} 45^{\prime} \mathrm{E}, 26^{\circ} 19^{\prime} \mathrm{N}, 1244 \mathrm{~m}\right)$ in 1961-2013, the mean annual temperature is $15.2{ }^{\circ} \mathrm{C}$, with temperatures of $5.2^{\circ} \mathrm{C}$ and $23.0^{\circ} \mathrm{C}$ in January and July, correspondingly. The considerably high and low temperatures are $34.7^{\circ} \mathrm{C}\left(16\right.$ May 2005) and $-11.1^{\circ} \mathrm{C}$ (9 February 1977), respectively. The growing degree days on the base of $5^{\circ} \mathrm{C}$ is $3743^{\circ} \mathrm{C}$. The mean annual precipitation is $1341 \mathrm{~mm}$, of which approximately 77\% falls between May and September. The mean annual sunshine duration is only $1189 \mathrm{~h}$, with a low sunshine percentage of less than $26 \%$.

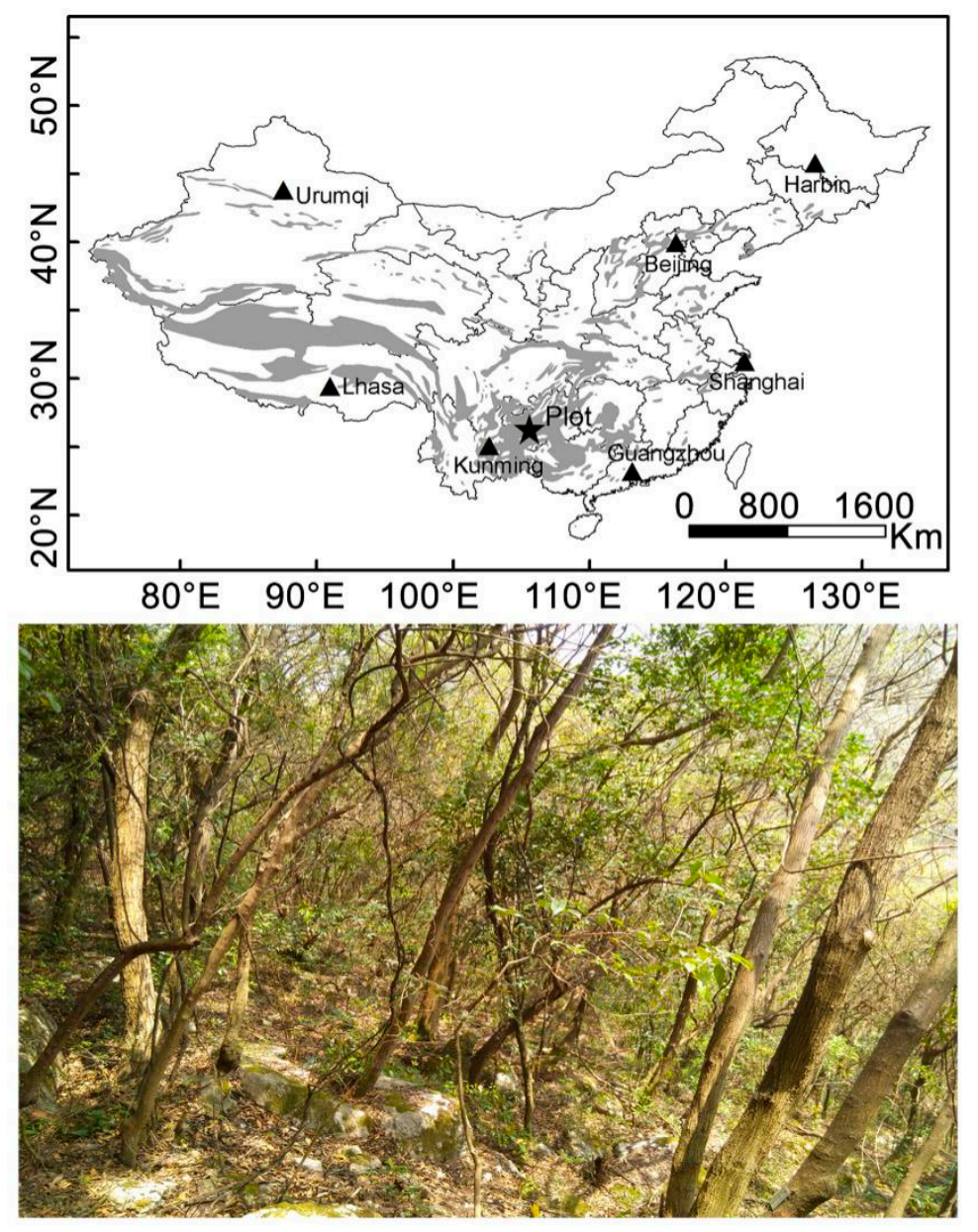

Figure 1. Location and interior view of the Tianlongshan permanent monitoring plot in the distribution map of karst terrain (grey) in China.

The plot $(2 \mathrm{ha}, 200 \mathrm{~m}$ horizontal $\times 100 \mathrm{~m}$ vertical $)$ is on the southern aspect and $31^{\circ}$ slope. Limestone outcrops are widely distributed, thereby resulting in a soil coverage of $55 \%$. The soil is a brown limestone soil (rendzina in the Food and Agriculture Organization of the United Nation soil classification system) with a shallow soil depth of less than $50 \mathrm{~cm}$ but with relatively abundant soil nutrients. The secondary evergreen and deciduous broad-leaved mixed forest in the stem exclusion phase in the plot is the most protected local forest which was restored from a clear cutting in 1958. Lithocarpus confinis Huang, Platycarya strobilacea Sieb., Itea yunnanensis Franch., and 
Machilus cavaleriei H. Lév. are four dominant species of the forest (botanical nomenclature was based on [50]). Carpinus pubescens Burkill, Pittosporum brevicalyx (Oliv.), Lindera communis Hemsl., Celtis sinensis Pers., Ilex coralline Franch., Rhamnella franguloides (Maxim.), and Fraxinus chinensis Roxb. are the common accompanying tree species. Stachyurus obovatus (Rehd.), Zanthoxylum dimorphophyllum Hemsl., and Rhamnus heterophylla Oliv. are the three most common shrub species, and Dallergia hancai Benth is the key liana species.

The living vegetation in the plot was investigated completely in summer 2012 and underwent a census again in summer 2015. Each woody plant with DBH $\geq 1 \mathrm{~cm}$ was labelled and located (relative coordinates), and its species, DBH, height (or length for lianas), and canopy width were recorded. All newly deceased individuals (mortality) and newly added individuals (recruitment) with DBH $\geq 1 \mathrm{~cm}$ in 2012-2015 were carefully determined and recorded.

Liu et al. [33] estimated the aboveground biomass of this forest on the basis of the data obtained from 2012 by biomass allometric functions. We used the same biomass allometric functions to estimate the aboveground biomass in 2015. The $\mathrm{ANPP}_{1 \mathrm{w}}$ was calculated as the aboveground biomass increment between 2012 and 2015 divided by the study time interval (3 years).

\section{Results}

\subsection{Mortality and Recruitment}

The species number of the individuals with DBH $\geq 1 \mathrm{~cm}$ decreased from 66 to 58 . Eight species, namely, Bothrocaryum controversum (Hemsl.), Rhus potaninii Maxim., Zanthoxylum armatum DC., Coriaria nepalensis Wall., Rhus chinensis Mill., Xylosma racemosum Miq., Smilax glaucochina Warb. and Paederia scandens (Lour.) Merr., disappeared because of death, and no new species appeared. The individual number declined from 16,821 to 15,003, among which 2578 individuals died (accounting for $15.3 \%$ of the total individual number in 2012), and 760 individuals were newly added (accounting for $5.1 \%$ of the total individual number in 2015) because most species indicated more deaths than recruitments. Thus, the net reduction was 1818 individuals (Table 1).

Table 1. Abundance variation, death number, and recruitment number of species in 2012-2015 of karst evergreen and deciduous broad-leaved mixed forest in Southwestern China.

\begin{tabular}{|c|c|c|c|c|c|c|c|}
\hline \multirow{2}{*}{ Species } & \multirow{2}{*}{$\begin{array}{l}\text { Evergreen/ } \\
\text { Deciduous }\end{array}$} & \multicolumn{2}{|c|}{ Abundance } & \multirow{2}{*}{$\begin{array}{c}\text { Net } \\
\text { Change }\end{array}$} & \multirow{2}{*}{ Death } & \multirow{2}{*}{$\begin{array}{l}\text { Percent of } \\
\text { Death }(\%)\end{array}$} & \multirow{2}{*}{ Recruitment } \\
\hline & & 2012 & 2015 & & & & \\
\hline \multicolumn{8}{|l|}{ Trees } \\
\hline Lithocarpus confinis Huang & Evergreen & 4346 & 3749 & -597 & 888 & 20.4 & 291 \\
\hline Platycarya strobilacea Sieb. & Deciduous & 3062 & 2654 & -408 & 464 & 15.2 & 56 \\
\hline Machilus cavaleriei H. Lév. & Evergreen & 2340 & 2004 & -336 & 411 & 17.6 & 75 \\
\hline Itea yunnanensis Franch. & Evergreen & 1869 & 1600 & -269 & 304 & 16.3 & 35 \\
\hline Carpinus pubescens Burkill & Deciduous & 705 & 702 & -3 & 23 & 3.3 & 20 \\
\hline Pittosporum brevicalyx (Oliv.) & Evergreen & 630 & 656 & 26 & 14 & 2.2 & 40 \\
\hline Lindera communis Hemsl. & Evergreen & 605 & 588 & -17 & 42 & 6.9 & 25 \\
\hline Celtis sinensis Pers. & Deciduous & 464 & 475 & 11 & 13 & 2.8 & 24 \\
\hline Ilex corallina Franch. & Evergreen & 308 & 287 & -21 & 33 & 10.7 & 12 \\
\hline Rhamnella franguloides (Maxim.) & Deciduous & 194 & 179 & -15 & 17 & 8.8 & 2 \\
\hline Fraxinus chinensis Roxb. & Deciduous & 154 & 156 & 2 & 8 & 5.2 & 10 \\
\hline Toona sinensis (A. Juss.) Roem. & Deciduous & 80 & 72 & -8 & 10 & 12.5 & 2 \\
\hline Cinnamomum bodinieri Levl. & Evergreen & 56 & 46 & -10 & 11 & 19.6 & 1 \\
\hline Machilus microcarpa Hemsl. & Evergreen & 47 & 47 & 0 & 1 & 2.1 & 1 \\
\hline Eriobotrya japonica (Thunb.) Lindl. & Evergreen & 43 & 37 & -6 & 7 & 16.3 & 1 \\
\hline Photinia tushanensis Yu & Evergreen & 37 & 36 & -1 & 3 & 8.1 & 2 \\
\hline Cerasus scopulorum (Koehne) Yu et Li & Deciduous & 31 & 27 & -4 & 5 & 16.1 & 1 \\
\hline Albizia julibrissin Durazz. & Deciduous & 24 & 21 & -3 & 4 & 16.7 & 1 \\
\hline Diospyros kaki Thunb. & Deciduous & 24 & 22 & -2 & 2 & 8.3 & 0 \\
\hline Ligustrum lucidum Ait. & Evergreen & 21 & 18 & -3 & 7 & 33.3 & 4 \\
\hline Ilex macrocarpa Oliv. & Deciduous & 18 & 16 & -2 & 2 & 11.1 & 0 \\
\hline Corylus heterophylla Fisch. & Deciduous & 13 & 8 & -5 & 5 & 38.5 & 0 \\
\hline Other tree species & & 19 & 17 & -2 & 2 & 10.5 & 0 \\
\hline
\end{tabular}


Table 1. Cont.

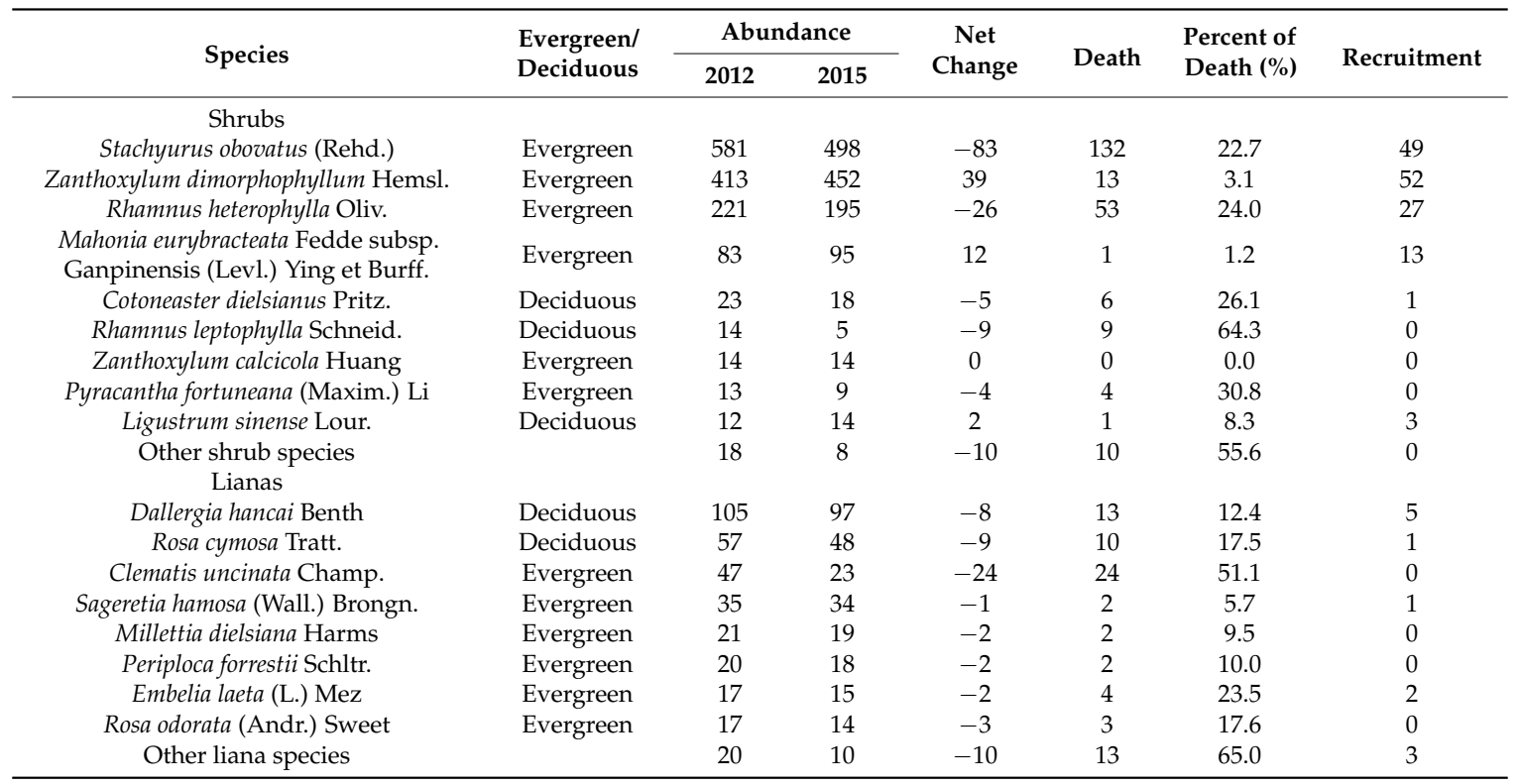

Among the 66 species in 2012, 53 species showed dead individuals, 31 species displayed recruitments, and 12 species exhibited neither death nor recruitment. In general, dominant species indicated numerous deaths and recruitments (Table 1). Forty-six species indicated more deaths than recruitments, one species exhibited equal death and recruitment, and only seven species denoted more recruitments than deaths.

Trees, lianas, and shrubs demonstrated the lowest (15.1\%), highest (21.5\%), and middle (16.5\%) mortality rates, correspondingly (Figure 2). Shrubs indicated a relatively high recruitment rate $(11.1 \%)$, whereas trees and lianas exhibited low recruitment rates (4.5\% and 5.1\%, respectively) (Figure 2).

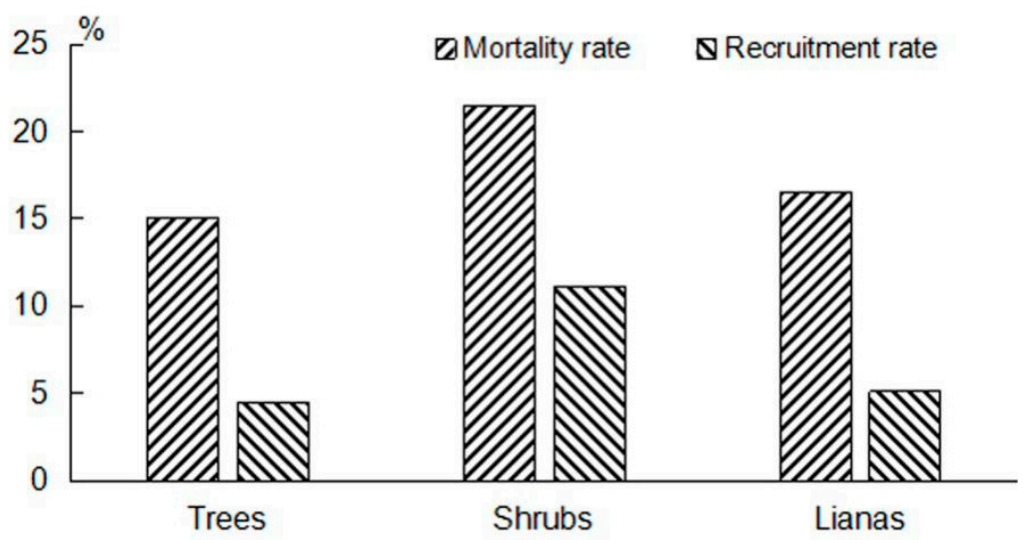

Figure 2. Mortality and recruitment rates of trees, shrubs, and lianas in 2012-2015 of karst evergreen and deciduous broad-leaved mixed forest in Southwestern China.

The number of deaths of individuals decreased with the increase in DBH classes (Figure 3). For trees, $77.2 \%$ of dead individuals (1757 individuals) belonged to the DBH class of $<5 \mathrm{~cm}$, and only nine individuals showed DBH $>15 \mathrm{~cm}$. The largest DBH of a dead tree was $21.8 \mathrm{~cm}$. For shrubs, $70.7 \%$ (162) belonged to the DBH class of $<2 \mathrm{~cm}$, and only eight individuals exhibited $\mathrm{DBH}>3 \mathrm{~cm}$. For lianas, $57.5 \%$ (42) belonged to the DBH class of $<2 \mathrm{~cm}$, and only 11 individuals showed $\mathrm{DBH}>3 \mathrm{~cm}$. 


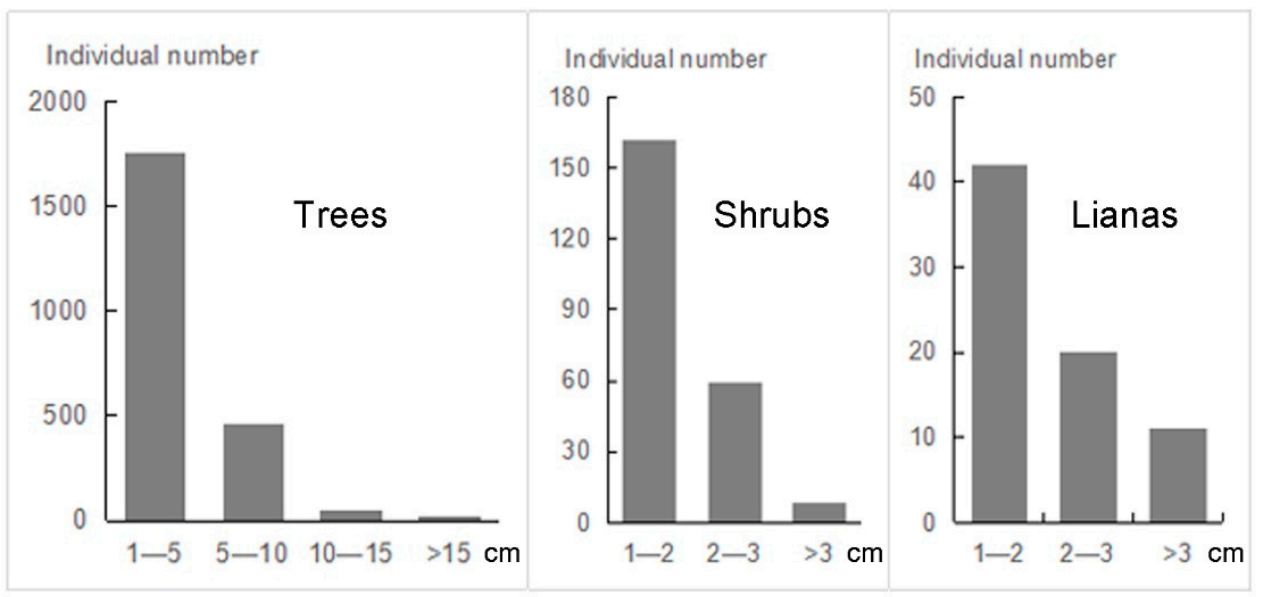

Figure 3. Numbers of death of individuals among the diameter at breast height (DBH) classes of trees, shrubs, and lianas in 2012-2015 of karst evergreen and deciduous broad-leaved mixed forest in Southwestern China.

\section{2. $A N P P_{l w}$}

The aboveground biomass of all living individuals with $\mathrm{DBH} \geq 1 \mathrm{~cm}$ was 138.04 and $163.26 \mathrm{t} \mathrm{ha}^{-1}$ in 2012 and 2015, correspondingly. The net aboveground biomass increment was $25.22 \mathrm{tha}^{-1}$. Thus, the $\mathrm{ANPP}_{\text {lw }}$ was $8.41 \mathrm{t} \mathrm{ha}^{-1}$ year $^{-1}$. Among the $\mathrm{ANPP}_{\mathrm{lw}_{\mathrm{w}}}$, the survivors, recruitments, and deaths contributed 10.88, 0.11 , and $-2.58 \mathrm{t} \mathrm{ha}^{-1}$ year $^{-1}$, respectively. Trees $\left(8.37 \mathrm{t} \mathrm{ha}^{-1}\right.$ year $\left.{ }^{-1}\right)$ accounted for nearly all of the forest $\mathrm{ANPP}_{\mathrm{lw}_{\mathrm{w}}}$, and were the major contributors. Shrubs $\left(0.04 \mathrm{tha}^{-1}\right.$ year $\left.^{-1}\right)$ and lianas $\left(-0.004 \mathrm{t} \mathrm{ha}^{-1}\right.$ year $\left.^{-1}\right)$ indicated considerably small contributions. L. confinis and P. strobilacea accounted for $71.2 \%\left(5.99 \mathrm{t} \mathrm{ha}^{-1}\right.$ year $\left.{ }^{-1}\right)$ of the forest $\mathrm{ANPP}_{\mathrm{lw}}$. Other species with $\mathrm{ANPP}_{\mathrm{lw}_{\mathrm{w}}} \geq 0.1 \mathrm{t} \mathrm{ha}^{-1}$ year $^{-1}$ were all trees, including I. yunnanensis (0.70), M. cavaleriei (0.37), C. pubescens (0.29), R. franguloides (0.26), P. brevicalyx (0.25), and C. sinensis (0.21).

\section{Discussion}

Short-term continuous monitoring data can still reveal important additional information on the cause of death, mortality, and recruitment rates and nature and direction of forest change assessment despite its limitations, especially when extrapolating short-term results to long-term dynamics [51-54]. Furthermore, lengthy census intervals may underestimate mortality rate and growth as a result of the growth of unrecorded individuals that are recruited and then died during the interval [55-57]. Thus, conducting short-term continuous monitoring of unstudied but important forest types (e.g., karst forest) is crucial, although long-term continuous monitoring should be conducted in future studies.

Changes in species composition differed in terms of vegetation type, succession stage, disturbance status, surrounding species pool, and study time interval [58]. Dominant species can regenerate in relatively balanced ecosystems with minimal disturbances. Thus, these species are commonly stable, whereas rare species $\left(\leq 1\right.$ individual ha ${ }^{-1}$ ) with low individual numbers will disappear given any individual death. Consequently, the fluctuation of species number in an ecosystem is determined mainly by the appearance or disappearance of rare species [59-61]. In the present disturbance-free (protected by the local government) karst forest, the species number of the individuals with $\mathrm{DBH} \geq 1 \mathrm{~cm}$ decreased from 66 to 58. Main species remained unchanged, and the eight species that disappeared all belonged to rare species.

The individual death numbers of the karst forest in 2012-2015 was 2578; most of these deaths belonged to small DBH classes, and the largest DBH of dead trees was only $21.8 \mathrm{~cm}$. The average DBH ( $5.0 \pm 4.2 \mathrm{~cm}$ in 2012 and $5.5 \pm 5.4 \mathrm{~cm}$ in 2015, correspondingly), height ( $5.4 \pm 2.4 \mathrm{~m}$ and $5.6 \pm 2.7 \mathrm{~m}$, correspondingly), and basal area (28.2 $\pm 0.0 \mathrm{~m}^{2} \mathrm{ha}^{-1}$ and $29.7 \pm 0.0 \mathrm{~m}^{2} \mathrm{ha}^{-1}$, correspondingly) of 
all individuals increased at different degrees, although the individual number decreased (the net reduction was 1818 individuals). This finding indicated that the karst forest is still growing. This type of forest has not reached the mature stage, although its aboveground biomass is not lower than that of mature karst forest in the Maolan National Nature Reserve in Southern Guizhou Province [43].

The mortality rate decreases first and subsequently increases with the increased tree DBH in nonkarst forests [62-67]. Small trees are in a weak position when competing for illumination, nutrition, and spatial resources; they are also vulnerable to diseases and pests [68]. Large trees commonly die with old age and are vulnerable to any natural and human disturbances [59]. Medium trees that grow vigorously exhibit advantages over small and large trees in intraspecific and interspecific competitions [69]. However, in a typical karst forest, the mortality rate directly decreased with the increase in the tree DBH. Medium trees $(5 \mathrm{~cm}<\mathrm{DBH} \leq 10 \mathrm{~cm})$ presented a significantly higher mortality rate than the relatively larger trees $(\mathrm{DBH}>10 \mathrm{~cm})(10.8 \%$ vs. $3.1 \%$, correspondingly). Medium trees showed a high mortality rate similar to that of small trees. This finding verified the special regeneration mode in karst forests; that is, saplings frequently replace small and medium trees that died on the vine, rather than replace old trees that aged naturally. The mortality rate of all individuals in the karst forest was 429.7 individuals $\mathrm{ha}^{-1}$ year $^{-1}$, which was significantly $(p<0.01)$ higher than that of nonkarst forests with rare disturbances (42.8-93.7 individuals $\mathrm{ha}^{-1} \mathrm{year}^{-1}$ ) and that of an intensively disturbed nonkarst forest (200.9 individuals $\mathrm{ha}^{-1}$ year $\left.^{-1}\right)$ in subtropical China $[21,22,24,70]$. This mortality rate was also significantly $(p<0.01)$ higher than that of Chinese and global forests in other climate zones (32.2-132.5 individuals $\mathrm{ha}^{-1}$ year ${ }^{-1}$ ) [26,71-74]. Many trees underwent increased deaths in karst landscapes with adverse habitats, thereby resulting in a high mortality rate in karst forests. However, the recruitment rate of the karst forest (126.7 individuals ha ${ }^{-1}$ year ${ }^{-1}$ ) is similar to that (33.0-190.3 individuals ha ${ }^{-1}$ year $^{-1}$ ) of nonkarst evergreen broad-leaved forests and evergreen and deciduous broad-leaved mixed forests in subtropical China [21,22,24].

$\mathrm{Ni}$ et al. [44] estimated the $\mathrm{ANPP}_{l_{\mathrm{w}}}$ of the same karst forest on the basis of two dominant tree species (i.e., P. strobilacea and M. cavaleriei) using the tree-ring width and girth increment methods. The estimated $\mathrm{ANPP}_{\mathrm{lw}}$ was $8.43 \mathrm{t} \mathrm{ha}^{-1}$ year $^{-1}$, which is similar to the result of the present study $\left(8.41 \mathrm{t} \mathrm{ha}^{-1}\right.$ year $\left.{ }^{-1}\right)$. However, the $\mathrm{ANPP}_{\mathrm{lw}}$ differed considerably among species. For example, the $\mathrm{ANPP}_{\mathrm{lw}}$ of the four dominant species, namely, L. confinis, P. strobilacea, M. cavaleriei, and I. Yunnanensis, were 3.33, 2.65, 0.37, and $0.70 \mathrm{t} \mathrm{ha}^{-1}$ year $^{-1}$, correspondingly. The selection of species based on the tree-ring width and girth increment methods exerted a noticeable effect on the $\mathrm{ANPP}_{l_{\mathrm{w}}}$ estimation result. However, the belowground $\mathrm{NPP}_{l_{\mathrm{w}}}\left(\mathrm{BNPP}_{l_{\mathrm{w}}}\right)$ of the karst forest was not estimated in either study. In the present study, we assumed that the below- and aboveground biomasses shared the same increment rate because the same volume growth rate of stem is commonly used when estimating root NPP through the growth rate reckoning algorithm; furthermore, the wood densities of root and stem were treated the same as in many biomass allometric function studies [31,75]. Consequently, the $\mathrm{BNPP}_{\mathrm{lw}}$ should be $1.24 \mathrm{tha}^{-1}$ year ${ }^{-1}$ because the $\mathrm{BNPP}_{1 \mathrm{w}}$-to-ANPP $\mathrm{Aw}_{\mathrm{w}}$ ratio equals the belowground-to-aboveground biomass ratio [33]. Thus, the total $\mathrm{NPP}_{1 \mathrm{w}}$ of the karst forest was $9.65 \mathrm{t} \mathrm{ha}^{-1}$ year -1 , which was in the low range of natural forest NPP (1.4-29.6 t ha ${ }^{-1} \mathrm{year}^{-1}$, mean $=13.6 \mathrm{t} \mathrm{ha}^{-1}$ year $^{-1}$ ) of subtropical Southwestern China [47] and lower than that of the global subtropical and tropical forests [42]. Soil pit, root coring, and allometric function methods remain highly recommended in exploring the BNPP of karst forests in future studies [33,76].

Plateau-surface is one of the eight karst morphological types in subtropical and northern-edge tropical climate zones of Southwestern China [49]. The species composition, community structure, and biomass allocation strategy of the different types of karst forests all indicate significant differences [33,35-37]. Thus, the regeneration dynamics of the different types of karst forests exhibit inevitable variances. For example, high-soil-coverage karst forests show more small trees and higher NPP than low-soil-coverage karst forests $[77,78]$. Other karst forests in different morphological types with different habitats, such as the peak-clump depression type in Southern Guizhou, the trough-valley type in Northern Guizhou, the peak-forest plain type in Northwestern Guangxi, and the fault basin 
type in Northeastern Yunnan, require continuously repeated observations to clarify their mortality, recruitment, and NPP features.

The forest is the largest gene bank and carbon reservoir in the global terrestrial ecosystem. Therefore, forests play a crucial role in global biodiversity maintenance and carbon cycling [12,79-82]. However, degraded vegetation and karst rocky desertification areas in karst regions replace the natural forest; these areas comprise most vegetation areas in Southwestern China [28]. The biodiversity and carbon storages are much lower in this degraded vegetation than in karst forests $[37,83]$. Therefore, increasing the forest coverage, promoting the regeneration dynamics, and strengthening the vegetation carbon fixation capacity (NPP) in karst regions can potentially combat rocky desertification, conserve biodiversity, and maintain sustainable development in Southwestern China.

\section{Conclusions}

We analysed the regeneration dynamics and $\mathrm{NPP}_{1 \mathrm{w}}$ of a karst forest in Southwestern China on the basis of a short-term continuous monitoring of a 2-ha plot for the first time. The karst forest presented higher mortality and lower $\mathrm{NPP}_{1 \mathrm{w}}$ than the nonkarst forests in subtropical China and in the world. However, the study time interval was brief; thus, long-term continuous monitoring of karst forests must be conducted in future studies.

Author Contributions: L.L. and J.N. conceived and designed the research; L.L. analyzed the data; Q.Z., G.H. and Z.Z. contributed field works; L.L. and J.N. wrote the paper.

Funding: This study was funded by the National Basic Research Program of China (2016YFC0502101, 2016YFC0502304), the National Science Foundation of China (41471049) and the Opening Fund of the State Key Laboratory of Environmental Geochemistry (SKLEG2017911).

Acknowledgments: Thanks to the Puding Karst Ecosystem Research Station for assistance in all field works.

Conflicts of Interest: The authors declare no conflict of interest.

\section{References}

1. Rees, M.; Condit, R.; Crawley, M.; Pacala, S.; Tilman, D. Long-term studies of vegetation dynamics. Science 2001, 293, 650-655. [CrossRef] [PubMed]

2. Davis, M.B. Retrospective studies. In Long-Term Studies in Ecology; Likens, D.E., Ed.; Springer: New York, NY, USA, 1989; pp. 3-20.

3. Pickett, S.T.A. Space-for-time substitution as an alternative to long term studies. In Long-Term Studies in Ecology; Likens, G.E., Ed.; Springer: New York, NY, USA, 1989; pp. 110-135.

4. Yang, H.C.; Xie, H.S. Study on the reconstruction of disturbance history of Pinus koraiensis mixed forest in Changbai Mountain. Acta Phytoecol. Sin. 1994, 18, 201-208. (In Chinese)

5. Hara, T. A model for mortality in a self-thinning plant population. Ann. Bot. 1985, 55, 667-674. [CrossRef]

6. Kenkel, N.C.; Hendrie, M.L.; Bella, I.E. A long-term study of Pinus banksiana population dynamics. J. Veg. Sci. 1997, 8, 241-254. [CrossRef]

7. Condit, R. Ecological implications of changes in drought patterns: Shifts in forest composition in Panama. Clim. Chang. 1998, 39, 413-427. [CrossRef]

8. Umeki, K.; Kikuzawa, K. Long-term growth dynamics of natural forests in Hokkaido, northern Japan. J. Veg. Sci. 1999, 10, 815-824. [CrossRef]

9. Hou, J.H.; Huang, J.H.; Ma, K.P. Eleven-year population growth dynamics of major species in a Quercus Liaotungensis forest in the Dongling mountains, northern China. Acta Phytoecol. Sin. 2004, 28, 609-615. (In Chinese)

10. Condit, R. Research in large, long-term tropical forest plots. Trends Ecol. Evol. 1995, 10, 18-22. [CrossRef]

11. Takahashi, K.; Mitsuishi, D.; Uemura, S.; Suzuki, J.I.; Hara, T. Stand structure and dynamics during a 16-year period in a sub-boreal conifer-hardwood mixed forest, northern Japan. For. Ecol. Manag. 2003, 174, 39-50. [CrossRef] 
12. Anderson-Teixeira, K.J.; Davies, S.J.; Bennett, A.C.; Gonzalez-Akre, E.B.; Muller-Landau, H.C.; Wright, S.J.; Abu Salim, K.; Almeyda Zambrano, A.M.; Alonso, A.; Baltzer, J.L.; et al. CTFS-ForestGEO: A worldwide network monitoring forests in an era of global change. Glob. Chang. Biol. 2015, 21, 528-549. [CrossRef] [PubMed]

13. Fang, J.Y.; Chen, A.P.; Peng, C.H.; Zhao, S.Q.; Ci, L.J. Changes in forest biomass carbon storage in China between 1949 and 1998. Science 2001, 292, 2320-2322. [CrossRef] [PubMed]

14. Fang, J.Y.; Sanders, N.J. Multi-scale patterns of forest structure and species composition in relation to climate in northeast China. Ecography 2012, 35, 1072-1082. [CrossRef]

15. Manchester, S.R.; Chen, Z.D.; Lu, A.M.; Uemura, K. Eastern Asian endemic seed plant genera and their paleogeographic history throughout the northern hemisphere. J. Syst. Evol. 2009, 47, 1-42. [CrossRef]

16. Piao, S.L.; Fang, J.Y.; Ciais, P.; Peylin, P.; Huang, Y.; Sitch, S.; Wang, T. The carbon balance of terrestrial ecosystems in China. Nature 2009, 458, 1009-1013. [CrossRef] [PubMed]

17. Pan, Y.; Birdsey, R.A.; Fang, J.; Houghton, R.; Kauppi, P.E.; Kurz, W.A.; Phillips, O.L.; Shvidenko, A.; Lewis, S.L.; Canadell, J.G.; et al. A large and persistent carbon sink in the world's forests. Science 2011, 333, 988-993. [CrossRef] [PubMed]

18. Huang, S.N.; Li, Y.D.; Wang, B.S. Tree population mortality, recruitment and growth during a 15-year period of secondary succession in tropical montane rainforests at Jianfengling on Hainan Island, China. Acta Phytoecol. Sin. 2000, 24, 710-717. (In Chinese)

19. Peng, S.L.; Fang, W. Studies on dynamics of Castanopsis chinensis and Schima Superba population in forest succession of Dinghushan mountain. Acta Phytoecol. Sin. 1995, 19, 311-318. (In Chinese)

20. Peng, S.L.; Fang, W.; Ren, H.; Huang, Z.L.; Kong, G.H.; Yu, Q.F.; Zhang, D.Q. The dynamics on organization in the successional process of Dinghushan Cryptocarya community. Acta Phytoecol. Sin. 1998, 21, 245-249. (In Chinese)

21. Wang, Y.H.; Mi, X.C.; Chen, S.W.; Li, M.H.; Yu, M.J. Regeneration dynamics of major tree species during 2002-2007 in a subtropical evergreen broad-leaved forest in Gutianshan nature reserva in east China. Biodivers. Sci. 2011, 19, 178-189. (In Chinese)

22. Chen, X.R.; Chen, Y.Y.; Luo, Z.R.; Ding, B.Y. A 5-year mid-mountain subtropical evergreen broad-leaved forest study in Baishanzu, east China. J. Zhejiang A F Univ. 2013, 30, 821-829. (In Chinese)

23. Jin, Y.; Chen, J.H.; Mi, X.C.; Ren, H.B.; Ma, K.P.; Yu, M.J. Impacts of the 2008 ice storm on structure and composition of an evergreen broad-leaved forest community in eastern China. Biodivers. Sci. 2015, 23, 610-618. (In Chinese) [CrossRef]

24. Ge, J.L.; Xiong, G.M.; Deng, L.Q.; Zhao, C.M.; Shen, G.Z.; Xie, Z.Q. Community dynamics of a montane Fagus engleriana-Cyclobalanopsis multiervis mixed forest in Shennongjia, Hubei, China. Biodivers. Sci. 2012, 20, 643-653. (In Chinese)

25. Wu, G.; Dai, L.M. Structure and dynamics of a temperate deciduous-conifer mixed forest in Changbai Mountain. Acta Ecol. Sin. 1998, 18, 470-477. (In Chinese)

26. Wang, L.W.; Li, B.H.; Ye, J.; Bai, X.J.; Yuan, Z.Q.; Xing, D.L.; Lin, F.; Shi, S.; Wang, X.G.; Hao, Z.Q. Dynamics of short-term tree mortality in broad-leaved Korean pine (Pinus koraiensis) mixed forest in the Changbai mountains. Biodivers. Sci. 2011, 19, 260-270. (In Chinese)

27. Wang, H.J. Community Dynamic and Influencing Factors of 8 ha Dynamics Plots in Picea schrenkiana Forest in Tianshan Mountains. Master's Thesis, Xinjiang University, Ürümqi, China, 2016. (In Chinese)

28. Editorial Committee of Vegetation Map of the People's Republic of China (ECVMC), Chinese Academy of Sciences. Vegetation Map of the People's Republic of China (1:1 000 000); Geology Press: Xi'an, China, 2007. (In Chinese)

29. Jiang, Z.C.; Lian, Y.Q.; Qin, X.Q. Rocky desertification in Southwest China: Impacts, causes, and restoration. Earth-Sci. Rev. 2014, 132, 1-12. [CrossRef]

30. Liu, C.C.; Wei, Y.F.; Liu, Y.G.; Guo, K. Biomass of canopy and shrub layers of karst forest in Puding, Guizhou, China. Chin. J. Plant Ecol. 2009, 33, 698-705. (In Chinese)

31. Liu, Y.G.; Liu, C.C.; Wang, S.J.; Guo, K.; Yang, J.; Zhang, X.S.; Li, G.Q. Organic carbon storage in four ecosystem types in the karst region of southwestern China. PLoS ONE 2013, 8, e56443. [CrossRef] [PubMed]

32. Liu, C.C.; Liu, Y.G.; Guo, K.; Wang, S.J.; Liu, H.M.; Zhao, H.W.; Qiao, X.G.; Hou, D.J.; Li, S.B. Aboveground carbon stock, allocation and sequestration potential during vegetation recovery in the karst region of southwestern China: A case study at a watershed scale. Agric. Ecosyst. Environ. 2016, 235, 91-100. [CrossRef] 
33. Liu, L.B.; Wu, Y.Y.; Hu, G.; Zhang, Z.H.; Cheng, A.Y.; Wang, S.J.; Ni, J. Biomass of karst evergreen and deciduous broad-leaved mixed forest in central Guizhou province, southwestern China: A comprehensive inventory of a 2 ha plot. Silva Fennica 2016, 50, 1492. [CrossRef]

34. Guo, K.; Liu, C.C.; Dong, M. Ecological adaptation of plants and control of rocky-desertification on karst region of southwest China. Chin. J. Plant Ecol. 2011, 35, 991-999. (In Chinese) [CrossRef]

35. Zhang, Z.H.; Hu, G.; Zhu, J.D.; Ni, J. Stand structure, woody species richness and composition of subtropical karst forests in Maolan, south-west China. J. Trop. For. Sci. 2012, 24, 498-506.

36. Zhang, Z.H.; Hu, G.; Zhu, J.D.; Ni, J. Aggregated spatial distributions of species in a subtropical karst forest, southwestern China. J. Plant Ecol. 2013, 6, 131-140. [CrossRef]

37. Ni, J.; Luo, D.H.; Xia, J.; Zhang, Z.H.; Hu, G. Vegetation in karst terrain of southwestern China allocates more biomass to roots. Solid Earth 2015, 6, 799-810. [CrossRef]

38. Wen, L.; Song, T.Q.; Du, H.; Wang, K.L.; Peng, W.X.; Zeng, F.P.; Zeng, Z.X.; He, T.G. The succession characteristics and its driving mechanism of plant community in karst region, southwest China. Acta Ecol. Sin. 2015, 35, 5822-5833. (In Chinese) [CrossRef]

39. Murphy, P.G.; Luge, A.E. Structure and biomass of a subtropical dry forest in Puerto Rico. Biotropica 1986, 18, 89-96. [CrossRef]

40. McLaren, K.P.; McDonald, M.A. Coppice regrowth in a disturbed tropical dry limestone forest in Jamaica. For. Ecol. Manag. 2003, 180, 99-111. [CrossRef]

41. RuizJaé, M.C.; Aide, T.M. Vegetation structure, species diversity and ecosystem processes as measures of restoration success. For. Ecol. Manag. 2005, 218, 159-173.

42. Felfili, J.M.; Nascimento, A.R.T.; Fagg, C.W.; Meirelles, E.M. Floristic composition and community structure of a seasonally deciduous forest on limestone outcrops in Central Brazil. Revista Brasileira De Botânica 2007, 30, 611-621. [CrossRef]

43. Zhu, S.Q.; Wei, L.M.; Chen, Z.R.; Zhang, C.G. A preliminary study on biomass components of karst forest in Maolan of Guizhou province, China. Acta Phytoecol. Sin. 1995, 19, 358-367. (In Chinese)

44. Ni, J.; Xu, H.Y.; Liu, L.B. Low net primary productivity of dominant tree species in a karst forest, southwestern China: First evidence from tree ring width and girth increment. Acta Geochim. 2017, 36, 482-485. [CrossRef]

45. Ni, J.; Zhang, X.S.; Scurlock, J.M.O. Synthesis and analysis of biomass and net primary productivity in Chinese forests. Ann. For. Sci. 2001, 58, 351-384. [CrossRef]

46. Luyssaert, S.; Inglima, I.; Jung, M.; Richardson, A.D.; Reichstein, M.; Papale, D.; Piao, S.L.; Schulze, E.D.; Wingate, L.; Matteucci, G.; et al. $\mathrm{CO}_{2}$ balance of boreal, temperate, and tropical forests derived from a global database. Glob. Chang. Biol. 2007, 13, 2509-2537. [CrossRef]

47. Liu, L.B.; Yang, H.M.; Xu, Y.; Guo, Y.M.; Ni, J. Forest biomass and net primary productivity in southwestern China: A meta-analysis focusing on environmental driving factors. Forests 2016, 7, 173. [CrossRef]

48. Editorial Board of "The Forest of Guizhou". The Forest of Guizhou; Guizhou Science and Technology Publishing House: Guiyang, China, 1992.

49. National Development and Reform Commission. Comprehensive Planing Brief of Rocky Desertification in Karst Area (Year 2006-2015); National Development and Reform Commission: Beijing, China, 2008. (In Chinese)

50. Chen, Q.H. Flora Guizhouensis; Guizhou Science and Technology Publishing House: Guiyang, China, 1982-2004. (In Chinese)

51. Harcombe, P.A.; Marks, P.L. Five years of tree death in a Fagus-Magnolia forest. Oecologia 1983, 57, 49-54. [CrossRef] [PubMed]

52. Harcombe, P.A. Tree Life Table. Simple birth, growth, and death data encapsu late life histories and ecological roles. BioScience 1987, 37, 557-574. [CrossRef]

53. Nakashizuka, T. Population dynamics of coniferous and broad-leaved trees in a Japanese temperate mixed forest. J. Veg. Sci. 1991, 2, 413-418. [CrossRef]

54. Nakashizuka, T.; Iida, S.; Tanaka, H.; Shibata, M.; Abe, S.; Masaka, T.; Niiyama, K. Community dynamics of Ogawa Forest Reserve, a species rich deciduous forest, central Japan. Vegetatio 1992, 103, 105-112.

55. Lewis, S.L.; Phillips, O.L.; Sheil, D.; Vinceti, B.; Baker, T.R.; Brown, S.; Graham, A.W.; Higuchi, N.; Hilbert, D.W.; Laurance, W.F.; et al. Tropical forest tree mortality, recruitment and turnover rate: Calculation, interpretation and comparison when census intervals vary. J. Ecol. 2004, 92, 929-944. [CrossRef] 
56. Brienen, R.J.; Phillips, O.L.; Feldpausch, T.R.; Gloor, E.; Baker, T.R.; Lloyd, J.; Lopez-Gonzalez, G.; Monteagudo-Mendoza, A.; Malhi, Y.; Lewis, S.L.; et al. Long-term decline of the Amazon carbon sink. Nature 2015, 519, 344-348. [CrossRef] [PubMed]

57. Chen, H.Y.H.; Luo, Y.; Reich, P.B.; Searle, E.B.; Biswas, S.R. Climate change-associated trends in net biomass change are age dependent in western boreal forests of Canada. Ecol. Lett. 2016, 19, 1150-1158. [CrossRef] [PubMed]

58. Condit, R.; Hubbell, S.P.; Foster, R.B. Short-term dynamics of a neotropical forest. BioScience 1992, 42, 822-828. [CrossRef]

59. Miura, M.; Manabe, T.; Nishimura, N.; Yamamoto, S. Forest canopy and community dynamics in a temperate old-growth evergreen broad-leaved forest, southwestern Japan: A 7-year study of a 4-ha plot. J. Ecol. 2001, 89, 841-849. [CrossRef]

60. Ayyappan, N.; Parthasarathy, N. Short-term changes in tree population in a tropical evergreen forest at Varagalaiar, western Ghats, India. Biodivers. Conserv. 2004, 13, 1843-1851. [CrossRef]

61. Werneck, M.D.S.; Franceschinelli, E.V. Dynamics of a dry forest fragment after the exclusion of human disturbance in southeastern Brazil. Plant Ecol. 2004, 174, 339-349. [CrossRef]

62. Monserud, R.A.; Sterba, H. Modeling individual tree mortality for Austrian forest species. For. Ecol. Manag. 1999, 113, 109-123. [CrossRef]

63. Lorimer, C.G.; Dahir, S.E.; Nordheim, E.V. Tree mortality rates and longevity in mature and old-growth hemlock-hardwood forests. J. Ecol. 2001, 89, 960-971. [CrossRef]

64. Umeki, K. Tree mortality of five major species on Hokkaido island, northern Japan. Ecol. Res. 2002, 17, 575-589. [CrossRef]

65. Coomes, D.A.; Duncan, R.P.; Allen, R.B.; Truscott, J. Disturbances prevent stem size-density distributions in natural forests from following scaling relationships. Ecol. Lett. 2003, 6, 980-989. [CrossRef]

66. Coomes, D.A.; Allen, R.B. Mortality and tree-size distributions in natural mixed-age forests. J. Ecol. 2007, 95, 27-40. [CrossRef]

67. Chao, K.J.; Phillips, O.L.; Gloor, E.; Monteagudo, A.; Torres-Lezama, A. Growth and wood density predict tree mortality in Amazon forests. J. Ecol. 2008, 96, 281-292. [CrossRef]

68. Guarin, A.; Taylor, A.H. Drought triggered tree mortality in mixed conifer forests in Yosemite National Park, California, USA. For. Ecol. Manag. 2005, 218, 229-244. [CrossRef]

69. Purves, D.W.; Lichstein, J.W.; Strigul, N.; Pacala, S.W. Predicting and understanding forest dynamics using a simple tractable model. Proc. Natl. Acad. Sci. USA 2008, 105, 17018-17022. [CrossRef] [PubMed]

70. Zhang, C.; Huang, D.Z.; Shi, J.H.; Li, L.; Wei, S.G.; Li, J. Dynamics and causes of woody plant death in the monsoon evergreen broad-leaved forest in Dinghushan Nature Reserve. Acta Ecol. Sin. 2006, 26, 2457-2462.

71. Condit, R.; Ashton, P.S.; Manokaran, N.; LaFrankie, J.V.; Hubbell, S.P.; Foster, R.B. Dynamics of the forest communities at Pasoh and Barro Colorado: Comparing two 50-ha plots. Philos. Trans. Biol. Sci. 1999, 354, 1739-1748. [CrossRef] [PubMed]

72. Hoshino, D.; Nishimura, N.; Yamamoto, S. Dynamics of major conifer and deciduous broad-leaved tree species in an old-growth Chamaecyparis obtusa forest, central Japan. For. Ecol. Manag. 2002, 159, 133-144. [CrossRef]

73. Gomes, E.P.; Mantovani, W.; Kageyama, P.Y. Mortality and recruitment of trees in a secondary montane rain forest in southeastern Brazil. Braz. J. Biol. 2003, 63, 47-60. [CrossRef] [PubMed]

74. Zhang, Z.C.; Hao, Z.Q.; Ye, J.; Lin, F.; Yuan, Z.Q.; Xing, D.L.; Shi, S.; Wang, X.G. Short-term death dynamics of trees in natural secondary poplar-birch forest in Changbai Mountains of Northeast China. Chin. J. Appl. Ecol. 2013, 24, 303-310. (In Chinese)

75. Luo, T.X. Patterns of Net Primary Productivity for Chinese Major Forest Types and Their Mathematical Models; The Commission for Integrated Survey of Natural Resources, Chinese Academy of Sciences: Beijing, China, 1996. (In Chinese)

76. Park, B.B.; Yanai, R.D.; Vadeboncoeur, M.A.; Hamburg, S.P. Estimating root biomass in rocky soils using pits, cores, and allometric equations. Soil Sci. Soc. Am. J. 2007, 71, 206-213. [CrossRef]

77. Luo, D.H. Biomass and Net Primary Productivity in Different Successional Stages of Karst Vegetation in Maolan, Guizhou Province, SW China. Master's Thesis, East China Normal University, Shanghai, China, 2009. (In Chinese) 
78. Zhang, Z.H. Ecological Research on Population and Community Stability in Karst Forest Vegetation. Ph.D. Thesis, East China Normal University, Shanghai, China, 2010. (In Chinese)

79. Dixon, R.K.; Brown, S.; Houghton, R.A.; Solomon, A.M.; Trexler, M.C.; Wisniewski, J. Carbon pools and flux of global forest ecosystems. Science 1994, 263, 185-190. [CrossRef] [PubMed]

80. Schimel, D.S.; House, J.I.; Hibbard, K.A.; Bousquet, P.; Ciais, P.; Peylin, P.; Braswell, B.H.; Apps, M.J.; Baker, D.; Bondeau, A.; et al. Recent patterns and mechanisms of carbon exchange by terrestrial ecosystems. Nature 2001, 414, 169-172. [CrossRef] [PubMed]

81. Pan, Y.D.; Birdsey, R.A.; Phillips, O.L.; Jackson, R.B. The structure, distribution, and biomass of the world's forests. Annu. Rev. Ecol. Evol. Syst. 2013, 44, 593-622. [CrossRef]

82. Köhl, M.; Lasco, R.; Cifuentes, M.; Jonsson, Ö.; Korhonen, K.T.; Mundhenk, P.; de Jesus Navar, J.; Stinson, G. Changes in forest production, biomass and carbon: Results from the 2015 UN FAO Global Forest Resource Assessment. For. Ecol. Manag. 2015, 352, 21-34. [CrossRef]

83. Liu, Y.G.; Liu, C.C.; Wei, Y.F.; Liu, Y.G.; Guo, K. Species composition and community structure at different vegetation successional stages in Puding, Guizhou province, China. Chin. J. Plant Ecol. 2011, 35, 1009-1018. (In Chinese)

(C) 2018 by the authors. Licensee MDPI, Basel, Switzerland. This article is an open access article distributed under the terms and conditions of the Creative Commons Attribution (CC BY) license (http://creativecommons.org/licenses/by/4.0/). 